\title{
フィールドデータに基づく高速鉄道の車輪摩耗特性解析
}

原 聡 ${ }^{* 1}$, 瞱道 佳明 ${ }^{* 2}$, 谷藤 克也 ${ }^{* 2}$

\section{Analysis of wheel wear characteristics of high-speed train based on field data}

\author{
Satoshi HARA ${ }^{* 1}$, Yoshiaki TERUMICHI ${ }^{* 2}$ and Katsuya TANIFUJI ${ }^{* 2}$ \\ ${ }^{* 1}$ Central Japan Railway Company \\ 1545-33 Ohyama, Komaki-shi, Aichi 485-0801, Japan \\ ${ }^{* 2}$ Department of Science and Technology, Sophia University \\ 7-1 Kioi-cho, Chiyoda-ku, Tokyo 102-8554, Japan
}

Received: 27 February 2019; Revised: 21 June 2019; Accepted: 25 August 2019

\begin{abstract}
A wheel/rail profile wear is a factor that affects the behavior of railway vehicles such as riding comfort, running stability, running safety and maintenance schedule. To predict wheel/rail profile wear theoretically with dynamic model of the vehicletrack systems, wear coefficient is necessary and these parameters are generally gained from laboratory test such as twin disk test. It is difficult to gain wear coefficient accurately from field data, because the wheel/rail contact conditions which decisive for wear have big variations. On the other hand, there are railway systems in which vehicles of the same type run on the dedicated track with the same operation pattern. In this case, there is possibility to generalize wear coefficient. In this study, we focus on this point, a large amount of wheel profiles from Tokaido Shinkansen, one of high-speed trains in Japan, was investigated. In this paper, wheel wear characteristics of coupled motion is pointed out and these wear characteristics are attempted to demonstrate from a view point of vehicle dynamics.
\end{abstract}

Keywords : Wheel/rail interaction, Wear development, Railway vehicle, Field data, Coupled train, Equivalent conicity

\section{1. 緒言}

鉄道における車輪とレールの接触状態は，走行安全性，走行安定性，乗り心地，曲線通過性能などその運動性 能に大きく関わるが，車両の走行により，車輪及びレールには必ず摩耗が発生するため，その形状を適切に管理 することは極めて重要である．車輪については研削や交換といった定期的なメンテナンスを鉄道事業者が行うこ とにより，踏面形状を適切に管理しているが，車輪はその材料費が他の部品と比較して大きいため，車輪の寿命 を延伸することは車両メンテナンスのコストダウンを実現する上で大変有効な手段となりうる．したがって，上 記の運動的側面及びメンテナンスコストダウンという両性質を考慮した上で車輪のメンテナンス周期の最適化を 考える場合，車輪の摩耗進展による形状変化を予測することは重要な課題である.

車輪/レール系の摩耗進展傾向を予測する方法は，実測データに基づく統計的・実測的予測法(斎藤他，2007) と車両運動シミュレーションを用いた理論的予測法（Jendel,2002）（Braghin et al., 2006）（金他，2009）（Pombo et al.,2010）（Tao et al.,2017）（Luo et al., 2017）がある．後者の理論的予測手法は，車両及び軌道の各種条件について 任意に条件変更が可能になるため，汎用性の高い手段となりうる．その手順としては，車輪／レール間の接触位 置や接触楕円，すべり率といった接触状態を車両運動シミュレーションにより算出し，そこで得られた物理量を いくつかの摩耗則に適用させる手法が取られている（谷藤，2012）。摩耗則は英国鉄道研究所（Pearce and Sherrat,1991)，ストックホルム王立工科大学 (Jendel,2002)，シェフィールド大学 (Lewis and Dweyer-Joyce,2004)

No.19-00091 [DOI:10.1299/transjsme.19-00091], J-STAGE Advance Publication date : 5 September, 2019

本論文は，第27回交通・物流部門大会 講演論文集(2018), No.1106の掲載内容に基づいた論文である.

*1 正員，東海旅客鉄道(株) 技術開発部（广485-0801 愛知県小牧市大山 1545-33）

*2 正員, フェロー, 上智大学 理工学部（广102-8554 東京都千代田区紀尾井町 7-1）

E-mail of corresponding author: satoshi.hara@jr-central.co.jp 
で導出されたものが適用される場合が多い。これらの摩耗則では，いずれも車輪摩耗の進み度合いを表す摩耗係 数を用いているが，この車輪摩耗係数の決定にあたっては主に 2 円筒転がり摩耗試験（Braghin et al., 2006）（下 川他，2010）（辻江他，2017）による室内試験で摩耗係数を同定することが一般的である. これはフィールドに おいては車両及び軌道の各種条件が互いに複雑に絡み合って作用し，その結果，車輪/レール間の接触状態が大 きくばらつくため, 普遍性のある結果を得ることが難しいとされているためである，一方で，フィールドにおい ては同形式車両が専用の軌道を同じ運行パターンで走行する鉄道システムが存在する．このような特徵を有する 鉄道システムにおいては, 車輪/レールの摩耗現象を一般化しやすく, フィールドにおける多岐に渡る変動要素 を考慮した摩耗係数を同定できる可能性がある，そこで著者らはこの点に着目し，東海道新幹線を走行する新幹 線車両を対象として，車輪の摩耗係数をフィールドデータから同定する方法について検討を行なうことにした. 本報では，フィールドデータに基づく高速鉄道の車輪摩耗に関する実測結果とこれらから導かれる車輪摩耗特性 について考察を加える.

\section{2. 車輪形状の実測と分析}

\section{$2 \cdot 1$ 調査対象}

調査対象は東海道新幹線を走行する N700A タイプの車両とした，選定理由は，同区間を走行する N700 系以降 の車両は，車両改造を施して N700A タイプに標準化されており，これら車両が一定の運用パターンのもと，高頻 度で走行するという特徵を有するため, 車輪の摩耗現象を比較的一般化しやすいと考えたためである. 図 1 に東 海道区間を走行する車両の編成構成図を示す，全ての車両が 16 両編成で構成されており，編成端部の 1 号車と 16 号車は付随車（以下， $\mathrm{T}$ 車）であり，中間号車は電動車（以下， $\mathrm{M}$ 車）である.

\begin{tabular}{|c|c|c|c|c|c|c|c|c|c|c|c|c|c|c|c|}
\hline 1 & 2 & 3 & 4 & 5 & 6 & 7 & 8 & 9 & 10 & 11 & 12 & 13 & 14 & 15 & 16 \\
\hline$T_{C}$ & $M$ & $M$ & $M$ & $M$ & $M$ & $M$ & $M$ & $M$ & $M$ & $M$ & $M$ & $M$ & $M$ & $M$ & \\
\hline
\end{tabular}

Fig. 1 Train set of Tokaido-Shinkansen line. All trains consist of 16 cars, it has 14 power unit cars and cars 1,16 are trailing unit. When it breaks in high speed, cars 2 to 15 are stopped by an electrical regenerative brake and this brakes are not applied in cars 1 and 16.

ここで, 車輪摩耗に影響を及ぼすと考えられるブレーキシステムと線形条件について述べる.ブレーキシステム について，高速域においては通常 $\mathrm{M}$ 車では電気ブレーキが作用するが，このとき $\mathrm{T}$ 車のブレーキ負担率は滑走 防止の観点から 0 としている（上野，菊野，2011）。一方, 駅停車時直前の低速域等においては, $\mathrm{M}$ 車 $\mathrm{T}$ 車とも に機械ブレーキが車輪板部に配置されたブレーキディスクに作用する，そのため，東海道新幹線における車輪摩 耗は，主として走行中の転動に起因して発生するものと考える．なお，ブレーキ中には車輪／レール間の粘着状 態の改善を目的とした研磨子が車輪踏面に作用寸るが，研磨子が車輪摩耗に及ぼす影響は小さいことが報告され ている（中橋他，2006）。続いて, 図 2 に東海道新幹線区間の線形条件（回送線や保守基地線内を含む）を示す. 高速走行するという特性上，直線区間が約 6 割と大半を占めており，都市鉄道等で多く存在する急曲線の割合は 非常に小さいという特徵を有する. そのため, 車輪フランジ部の摩耗量は都市鉄道と比較すると小さいと言える.

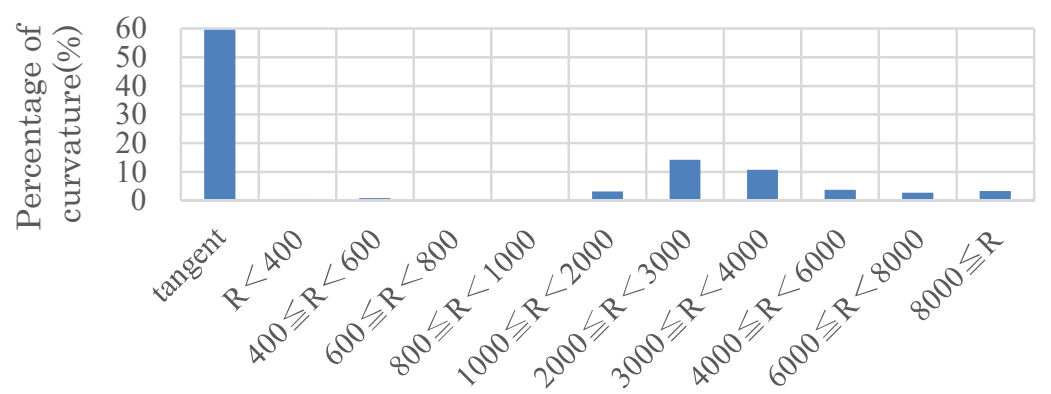

Fig. 2 Track geometry properties of Tokaido-Shinkansen line. Tangent section accounts for $60 \%$ of total line and there are less number of sharp curve to operate at high speed. 


\section{$2 \cdot 2$ 車輪形状分析方法}

車輪摩耗形状の測定は，車輪踏面形状測定器 MiniProf (Greenwood Engineering 社製) を用いた.

測定した車輪形状の摩耗評価を行うにあたり，下記(a)〜(d)の 4 つの指標を用いた. それぞれの定義を下記に示 す. なお，図 3 に示すように設計形状の車輪に対してフランジバック面を $\mathrm{Y}=0$ とし， $\mathrm{Y}=65 \mathrm{~mm}$ の Z 座標を 0 と する座標系を設定した．測定した車輪摩耗プロフィールは設計形状におけるフランジトップ位置で合わせた.

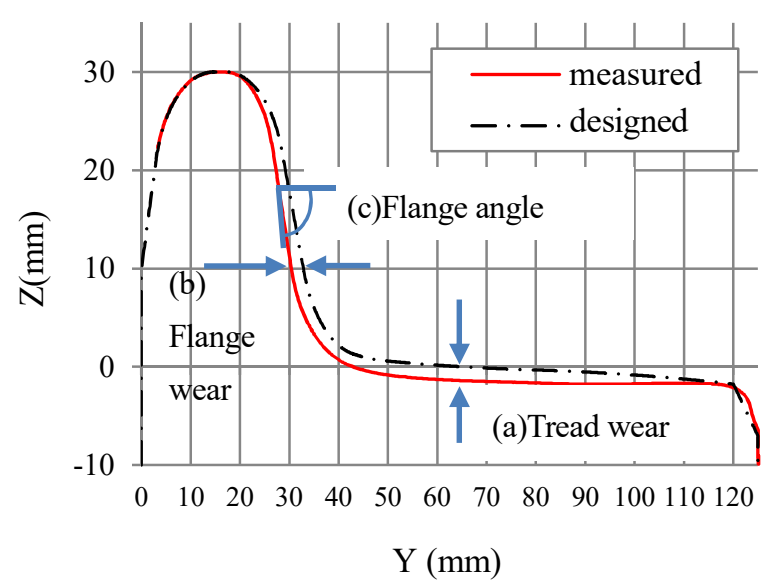

Fig.3 Coordinate of the wheel. The tread wear is defined by the difference at $Y=65 \mathrm{~mm}$. The flange wear is defined by difference at $\mathrm{Z}=10 \mathrm{~mm}$. The flange angle is calculated from linear approximation between $\mathrm{Z}=12 \mathrm{~mm}$ and $18 \mathrm{~mm}$.

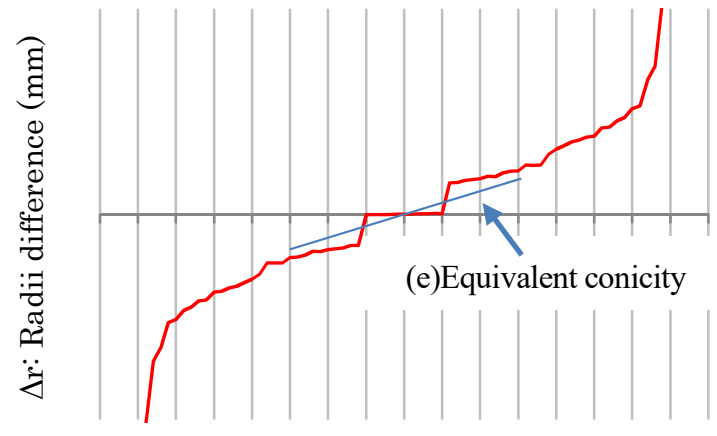

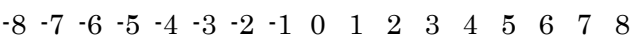

$\mathrm{y}$ : Lateral displacement of wheelset $(\mathrm{mm})$

(a) 踏面摩耗量 : $\mathrm{Y}=65 \mathrm{~mm}$ 位置の設計形状と摩耗形状の $\mathrm{Z}$ 方向の差

(b) フランジ摩耗量 : Z=10mm 位置の設計形状と摩耗形状の Y 方向の差

(c) フランジ角度 : $\mathrm{Z}=12 \sim 18 \mathrm{~mm}$ の 2 点間から求めた近似直線と水平方向の角度（足立他，2006）

(d) 等価踏面勾配 : 車輪の踏面勾配とレール頭頂面部の曲率によって生じる幾何学的な接触勾配であり，図 4 に示す輪軸左右変位量 $y$ に対する左右車輪の転がり半径差 $\Delta r の$ 関係図から,$y= \pm 3 \mathrm{~mm}$ 間において最小二 乗法に基づく線形近似を行い，その傾きの $1 / 2$ を等価踏面勾配と定義した.

なお，図 4 は摩耗車輪と $60 \mathrm{~kg}$ 設計レール形状との組み合わせによる一例の結果であり，接触幾何解析（足 立他，2006）により算出したものである.ここで輪軸左右変位 $y$ の取り方によって等価踏面勾配の值は変 化するが，他文献（角井他，2004）（清水他，2014）（Shi et al., 2017）において $y= \pm 3 \mathrm{~mm}$ で計算してい る事例が多いことを踏まえ，これら計算結果と比較できるよう本研究でも輪軸左右変位 $y= \pm 3 \mathrm{~mm}$ とした.

\section{$2 \cdot 3$ 調査結果}

累積走行距離が 55 万〜 60 万 km となる N700A タイプ（'N700A’ 及びN700 系を N700A に改造した 'N700 改 造車’の 2 車種）の車両を対象として測定した結果を以下に示す.ここで，走行距離と車輪摩耗の関係を厳密に 評価するために，途中で車輪研削したもの，車輪交換したものについては分析対象から除外した.

図 5 に編成内の輪軸別の(a)踏面摩耗量, (b)フランジ摩耗量, (c)フランジ角度, (d)等価踏面勾配について, N700A 計 15 編成分の平均值（Group A）と N700 改造車計 15 編成分の平均值（Group B）を示す。ここで，縦軸は各摩 耗指標における 1 号車 No1 軸の值を 1 としたときの比率を示す. 横軸の下段の数字は号車を表し, その上段の数 字は号車内における輪軸番号を表す，等価踏面勾配は対象とするレール形状によって異なる值をとるが，本論文

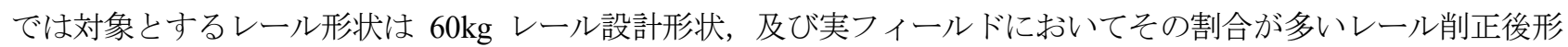
状（実測形状）の2 種類とした. 図 5(d)におけるレール削正後形状との組合せ結果（青線）は，60kgレール設計 形状との組合せにおける 1 号車 No1 軸の等価踏面勾配值を 1 としたときの比率である. 


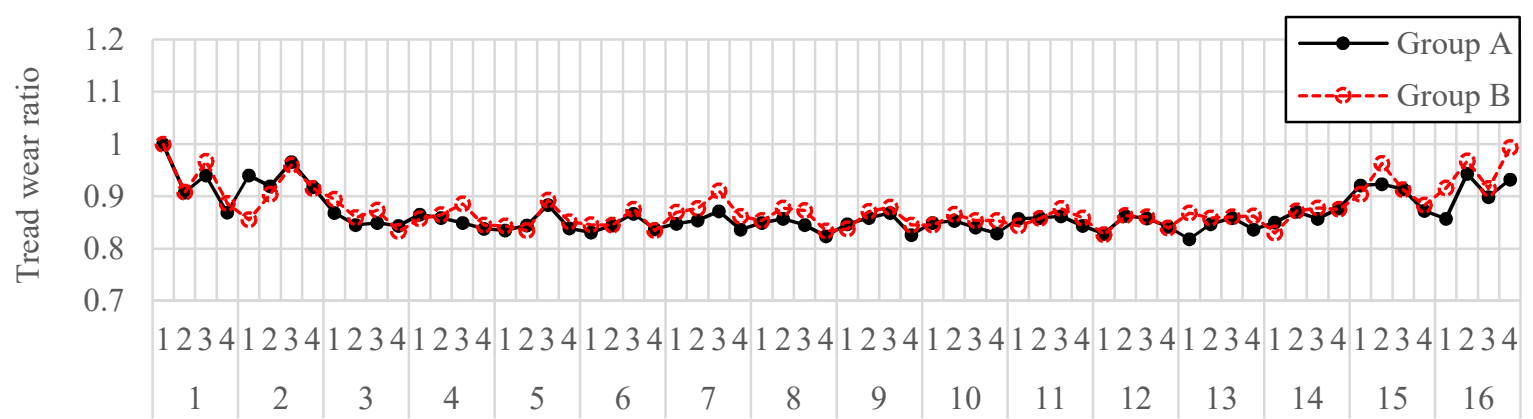

(a) Tread wear

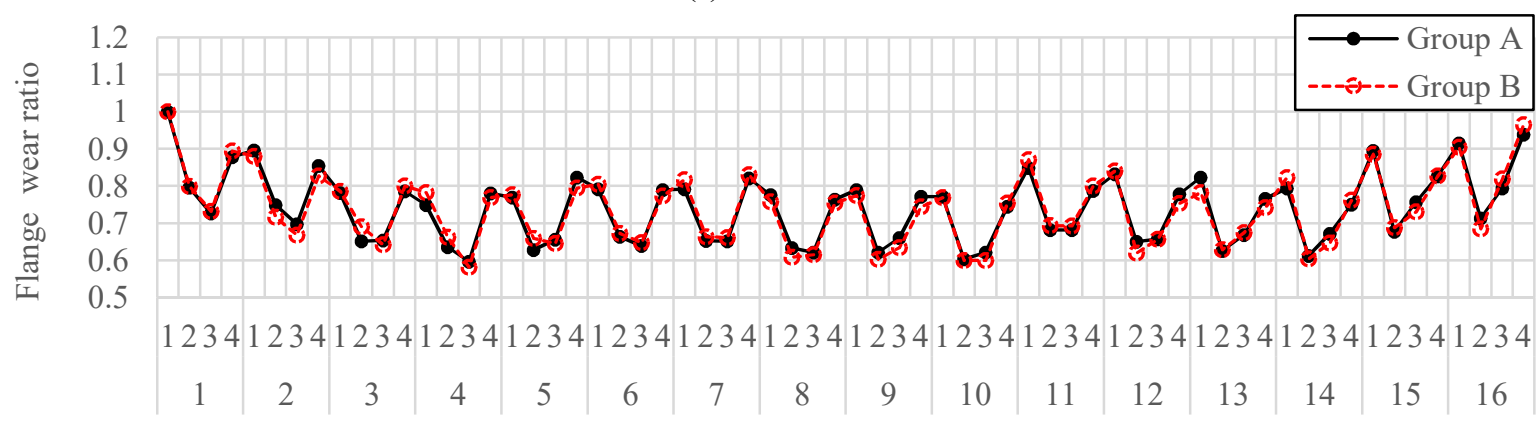

(b) Flange wear

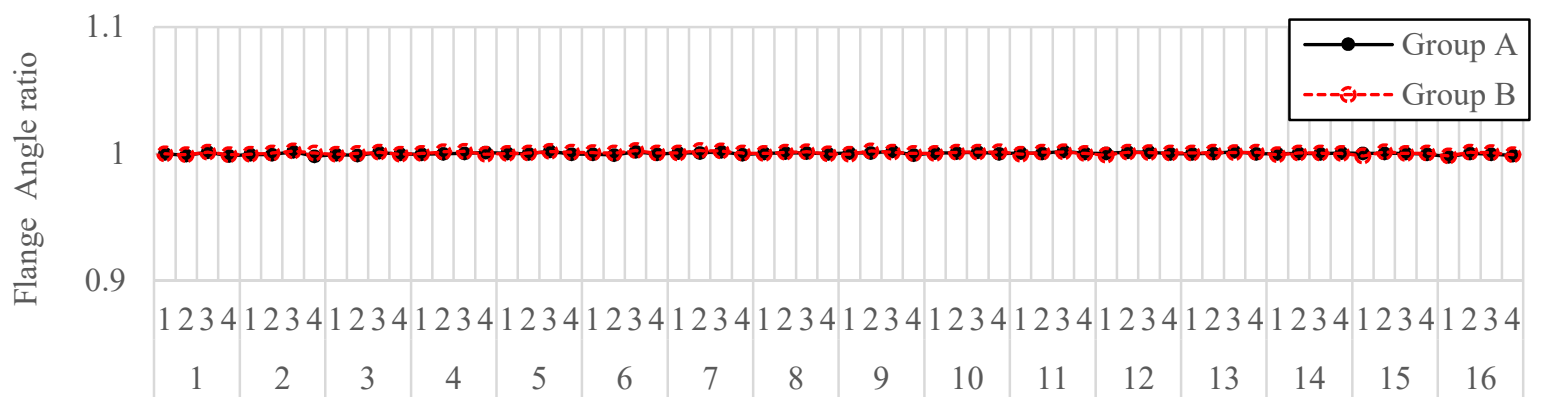

(c) Flange angle

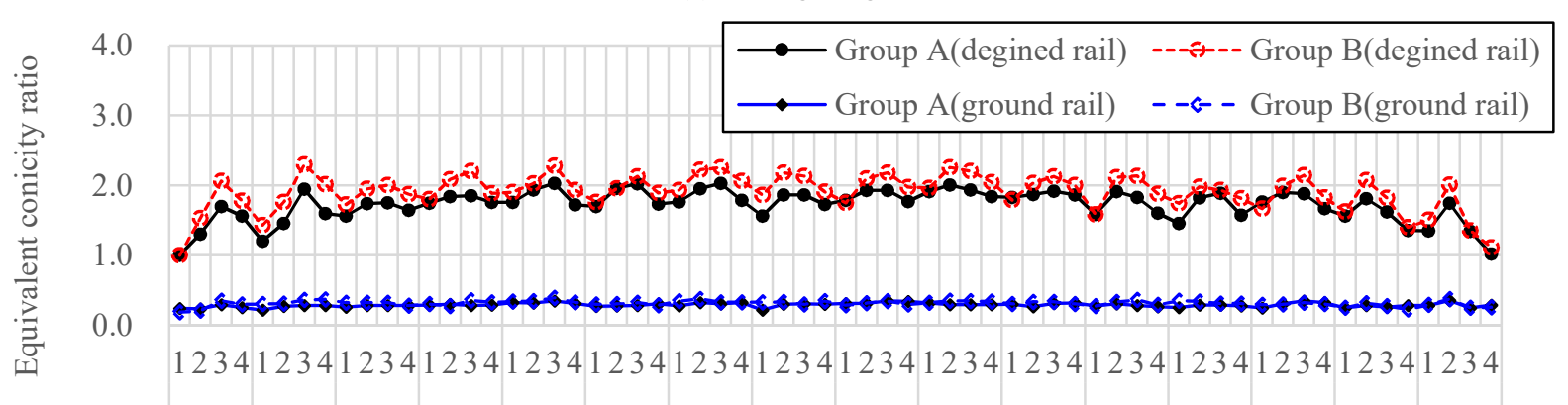

(d) Equivalent conicity

Fig.5 A comparison between Group A (Series N700A) and Group B (Series N700 renovated) about the 4 indicators at around running distance 550,000 600,000km. (a)Tread wear, (b)Flange wear, (c)Flange angle,(d)Equivalent conicity. The 4 indicators of wheel wear is almost same the between Group A and Group B. Compared to the intermediate car, the cars located at each end of the trainset (Cars 1,16) experience large amount of tread wear and flange wear. As for flange wear, a significant difference is observed between No.1,4 axle and No.2,3 axle. The amounts of flange angle is constant value. As for equivalent conicity, the cars located at each end of the trainset(Cars 1,16) experience a lower equivalent conicity than those at the middle of the trainset in combination with designed rail. On the other hand, equivalent conicity is constant regardless of the cars in combination ground rail. 
図 5 より, 各車輪摩耗指標が号車・輪軸番号毎にとる值は Group A と Group B で同程度であることが分かる. すなわち, 図 5(a)(b)より踏面摩耗及びフランジ摩耗は, 両者ともに編成端部寄りの号車である 1,2,15,16 号車の方 が中間号車(3～14 号車)よりも摩耗量が大きい傾向がある.このうちフランジ摩耗については，号車に寄らず輪 軸別の傾向が明らかであり, 号車端部の軸 (1,4 軸) の方が中間軸 (2,3 軸) よりも摩耗量が大きいことが分かる. フランジ角度は図 5(c)より両者ともに号車・輪軸番号によらず一定值をとることが分かる．等価踏面勾配につい ては，両者ともに 60kg 設計レール形状との組合せ結果では編成端部寄りの号車の方が中間号車よりも值が小さ くなる傾向がある. 一方, 削正後レール形状との組合せ結果では, その值は $60 \mathrm{~kg}$ 設計レール形状との組合せ結果 よりも小さい值をとり，その值は号車・輪軸番号によらず一定值をとる傾向がある。これは図 6 に示すように, 設計レール形状においては接触点は転がり半径の変化が大きいレール中心より内側に位置するのに対して, 削正 後レール形状においては接触点が転がり半径の変化が小さいレール中心よりも外側に位置するように削正してい るため (三輪他, 2012), 軌道変位などにより輪軸左右変位が発生しても輪径差が発生しにくくなっているためで ある，なお，実フィールドにおいては，設計レール形状（新品レール形状）を有するレール区間は全線の中での 割合は小さいため，削正後のレール形状との組み合わせの方が実態に近いと考える.
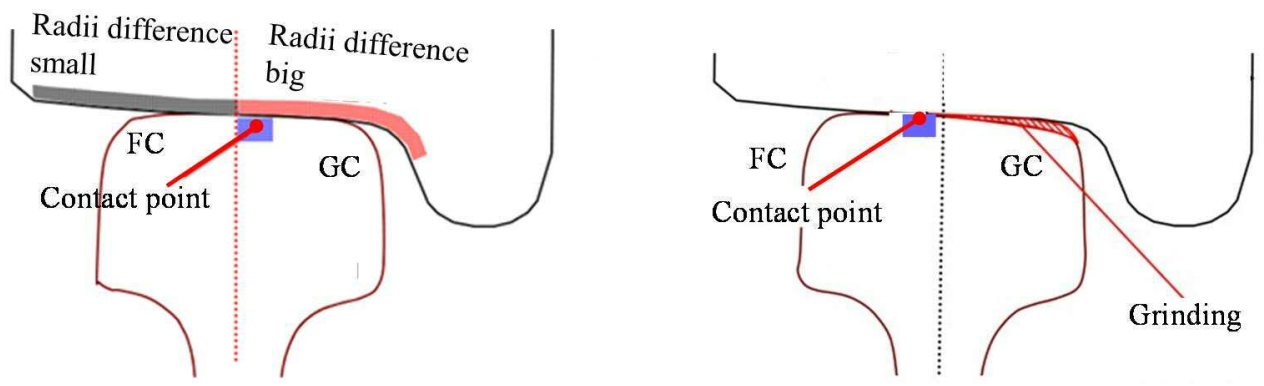

Fig.6 Comparison of neutral contact position (Left: designed rail shape, Right: target shape of ground rail). The contact point is positioned outside the rail center where the rolling radii difference is small in case of ground rail.

続いて, 号車別の車輪摩耗形状の傾向を把握するため, 号車別の車輪摩耗分布を調査した。ここで車輪摩耗分 布とは, 図 7 に示すように設計車輪断面形状と摩耗車輪断面形状の車輪半径方向の差分を摩耗量と定義した.

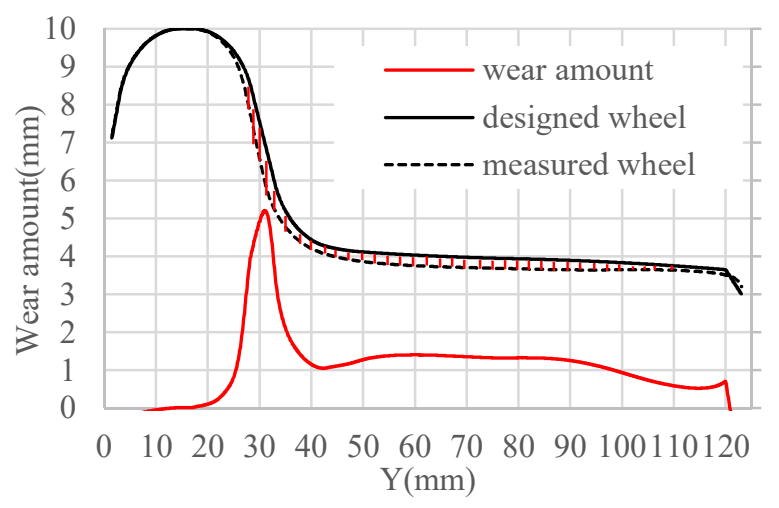

Fig.7 Wheel wear distribution.

図 8 に Group A と Group B について号車別の車輪摩耗分布を平均化した結果を示寸．ここでいう平均化した摩 耗分布とは, 編成毎に号車単位での平均摩耗分布（号車内の 8 車輪分の摩耗分布の平均）を算出し，さらに分析 した編成数 (今回の場合は 15 編成分) で平均化したものである. 図 8(a)は車輪踏面部 (図 7 における Y=40 110mm の箇所）の摩耗分布を，図 8(b)は車輪フランジ部（図 7 における Y=20 40mm の箇所）の摩耗分布を示したもの である。図 8 (a)(b)より, Group A と Group B の摩耗分布は, 摩耗のピーク位置及び号車毎の摩耗の大きさを含め 同じ傾向を示すことが確認される，また，号車毎に摩耗量の大きさは図 5(a)(b)に示したように異なるものの，摩 
耗分布形状は号車に依らず同じ形状を取ることが分かる.すなわち, 号車に依らず, 踏面部においては $\mathrm{Y}=60 \mathrm{~mm}$, $85 \mathrm{~mm}$ 付近には摩耗ピークがみられ，フランジ部においては $\mathrm{Y}=31 \mathrm{~mm}$ 付近に摩耗ピークがみられる.
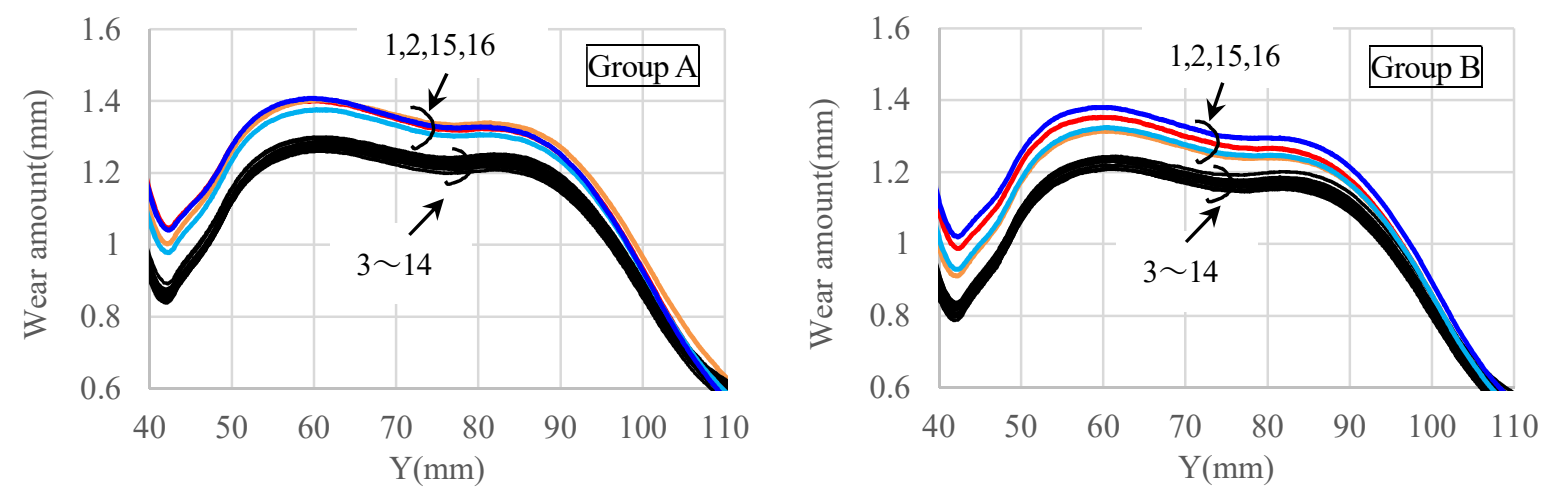

(a) Wear distribution in tread area
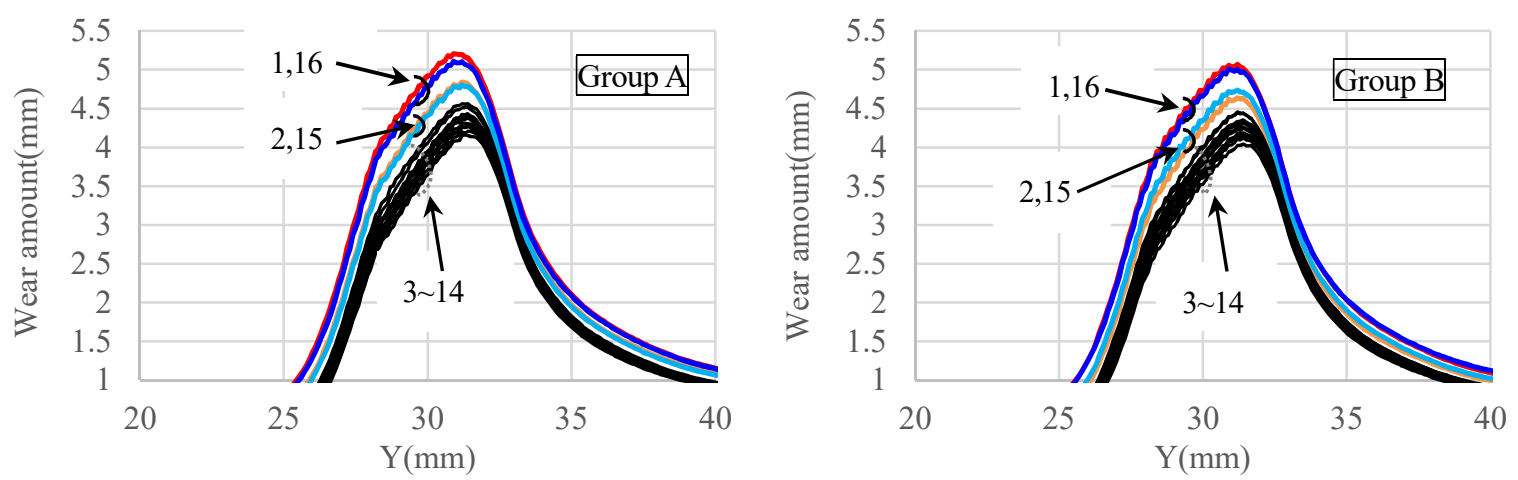

(b) Wear distribution in flange area

Fig.8 The result of wheel wear distrbution at running distance 550,000 to 600,000km. The Left is a result of Group A (Series N700A), and right one is Group B (Series N700 renovated). (a) Wear distribution in tread area, (b) Wear distribution in flange area. Wheel wear distribution is almost the same between Group A and Group B.

図 5,8 に示寸結果より, N700A タイプの号車・軸毎の各車輪摩耗指標量の大きさ，及びその摩耗分布の様子は 同程度であることを示した，車輪摩耗は表 1 に示寸多様な条件を反映した結果生じるものであるが，上述した結 果は，走行条件，車両性能が統一された状態にある鉄道システムでは，大量のフィールドデータを収集・分析す ることで，平均的な摩耗形状を一般化できることを示唆する．すなわち，車輪・レール間の接触点，接触面積， クリープカなどの接触状態は日々の走行条件によって複雑に変化するものではあるが，表 1 に示す要素全体の車 輪摩耗への寄与度は編成に寄らず同程度であることを意味する．よって，摩耗による車輪形状変化を予測する上 で必要となる摩耗係数についてフィールドデータから同定できる可能性があると考える. 従来研究における摩耗 係数の同定方法は，2 月筒転がり試験装置等による室内試験で実施されてきた。これら試験結果はある限られた 一定条件下における結果であり，フィールドにおいて多岐に変動する要素を考慮したものではないが，鉄道事業 者が有するフィールドデータから摩耗係数を同定できれば，より実態に即した摩耗進展予測ができると考える. 
Table1 Factors considered to influence wheel wear.

\begin{tabular}{|c|c|c|c|c|}
\hline & \multicolumn{4}{|c|}{ Factor } \\
\hline Track & $\begin{array}{l}\text { - Curve radius } \\
\text { - Material hardness }\end{array}$ & $\begin{array}{l}\cdot \text { Rail Profile } \\
\cdot \text { Rail surface rous }\end{array}$ & $\begin{array}{l}\text { - Track irregularity } \\
\text { Iness }\end{array}$ & etc \\
\hline Vehicle & $\begin{array}{l}\text { - Axle load } \\
\text { - Material hardness } \\
\text { - Frequency of accelerat }\end{array}$ & $\begin{array}{l}\text { - Operation speed } \\
\text { - Brake condition } \\
\text { ion / deceleration }\end{array}$ & $\begin{array}{l}\cdot \text { Wheel profile } \\
\text { - Wheel surface roughness } \\
\text { - Frequency of wheel idling / sliding }\end{array}$ & etc \\
\hline $\begin{array}{l}\text { Wheel/rail } \\
\text { interaction }\end{array}$ & $\begin{array}{l}\text { - Coefficient of friction } \\
\text { - Humidity }\end{array}$ & - Lubrication & - Temperature & etc \\
\hline
\end{tabular}

\section{3. 編成車両の車輪摩耗特性に関する考察}

本章では，第 2 章で記した $4 つ の$ 車輪摩耗指標(a)〜(d)のの結果について個別に考察を行う.

\section{$3 \cdot 1$ 踏面摩耗}

図 5(a), 図 8 (a)より踏面摩耗は, 編成端部寄りの号車である 1,2,15,16 号車の方が中間号車 (3〜14 号車) よりも 摩耗量が大きいことが分かる．編成端部の 1,16 号車は駆動力及び制動力を有していない $\mathrm{T}$ 車であるが, $\mathrm{T}$ 車の 方がM車よりも摩耗量が大きいという結果は, 加速または減速のための負荷トルクに伴い車輪接触面内に生じる すべりの増加以外にも他の因子が影響していることが示唆される. 編成の端部号車が大きくなる理由として, 車 輪通過に伴う車輪・レール間の摩擦係数の変化（滝野他，2013）, トンネル走行時等の最後尾車のヨーモードを主 体とする運動的要素（藤本他，1995）, ブレーキ作用時の自連力発生に伴う接線力の変化（坂本，山下，2018）な ぞの要素が考えられるが，これらの影響度を定量的に評価することが今後の課題となる．なお，MBS シミュレー ションを用いた最新の研究では, 摩擦係数が低いほうが踏面摩耗は増加する傾向があることが示されている (Casanueva et al., 2017).

また，図 8(a)に示す摩耗分布より，今回調査対象とした N700A では号車に依らず Y=60mm，85mm 付近に摩耗 ピークがみられる. 新品車輪の場合, 直線における設計形状レールとの組み合わせでは $\mathrm{Y}=69 \mathrm{~mm}$ 付近で接触する 計算結果となるが，この位置では摩耗のピークをとらず，摩耗ピーク位置は新品車輪と設計形状レールとの組合 せの場合では，いずれも車輪形状またはレール形状における曲率変化点近傍であることが分かる．つまり，図 9 に示すように $\mathrm{Y}=60 \mathrm{~mm}$ 付近の摩耗ピークは設計車輪形状においては $\mathrm{R} 650 \mathrm{~mm} ・ \mathrm{R} 1000 \mathrm{~mm}$ の曲率変化点近傍にあ り, $\mathrm{Y}=85 \mathrm{~mm}$ 付近の摩耗ピークは設計レール形状において $\mathrm{R} 600 \mathrm{~mm} ・ \mathrm{R} 50 \mathrm{~mm}$ の曲率変化点近傍にある. なお, $\mathrm{Y}=85 \mathrm{~mm}$ 付近は経験的に急曲線通過時における内軌側車輪でレールと接触する位置であるが，この近辺は設計車 輪形状において凸の R1000 mm で構成されており，レール接触時は接触圧が大きくなる部分である．このため， $\mathrm{Y}=85 \mathrm{~mm}$ 付近で摩耗ピークを取るのは急曲線通過時の輪軸左右移動が一因であると考えられる. 


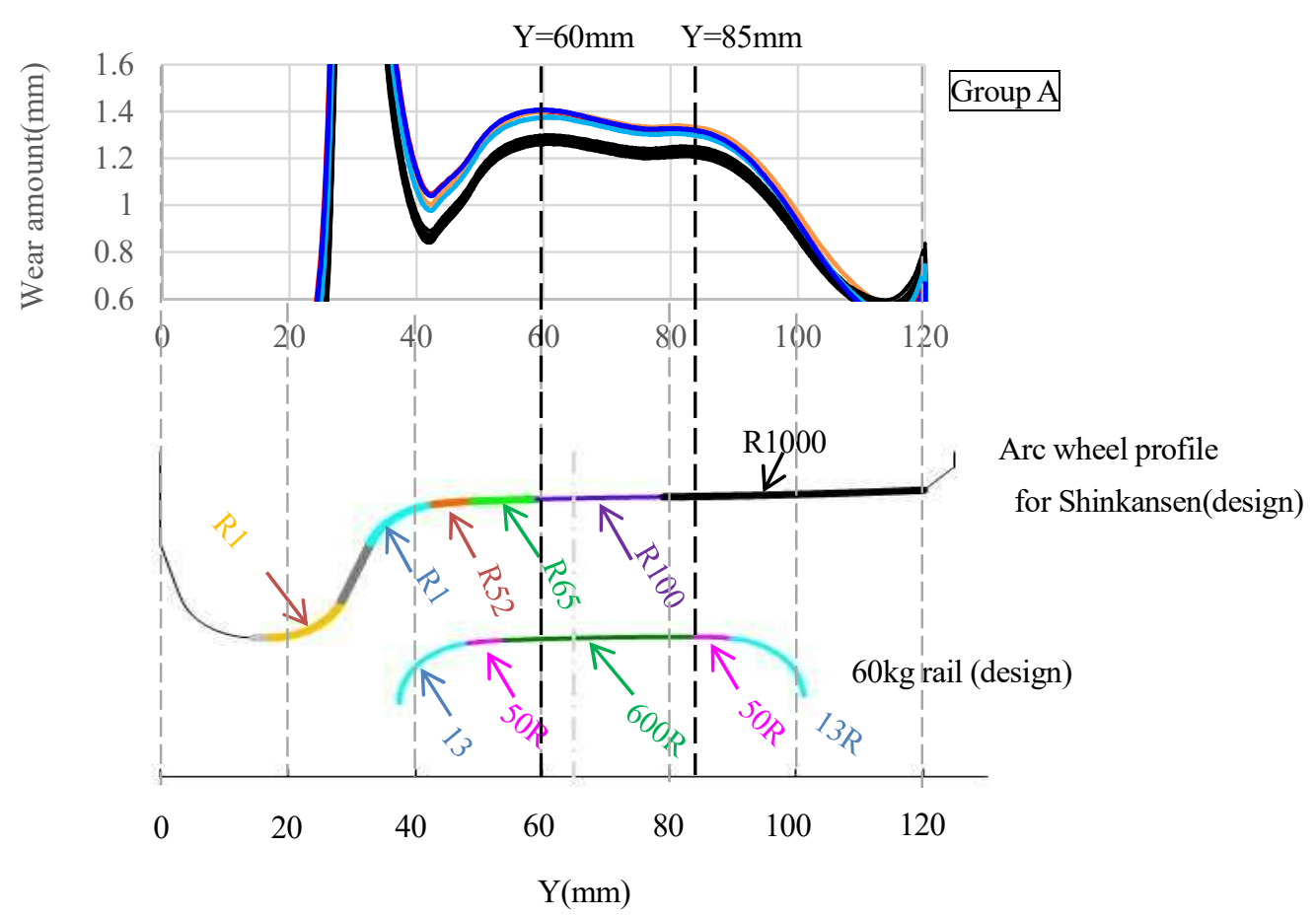

Fig.9 Relationship between wheel wear distribution and radii of curvature of designed contact shape. There are two peaks around $\mathrm{Y}=60 \mathrm{~mm}$ and $85 \mathrm{~mm}$ regardless of the cars. These peaks positions around the transition of curvature point.

\section{$3 \cdot 2$ フランジ摩耗}

図 5(b), 図 8(b)から，踏面部と同様に編成端部寄りの号車である 1,2,15,16 号車の方が中間号車 (3〜14 号車)よ りも摩耗量が大きいことが分かる。このうち，フランジ摩耗は号車に寄らず軸別の傾向が明らかであり，号車端 部の軸（1,4 軸）の方が中間軸（2,3 軸）よりも摩耗量が大きいことが分かる.この傾向は過去の新幹線電車の調 査結果と同様である (谷藤, 咲山, 1986). この点について, 図 10 に示す 1 車両運動モデルを用いて検証した. こ のモデルは，地震時における鉄道車両の挙動メカニズムを解明することを目的に開発された 2 次元平面内におけ る車両運動シミュレーションモデル（西村他, 2008) を 3 次元平面に拡張し, 曲線走行を可能としたものである. 車輪・レール間の接線方向成分は走行している場合には Kalker の接触理論に Levi-Chartet $の$ 飽和則を適用した非 線形クリープカが働くものとした．車両諸元は N700A タイプとし，車輪踏面は新幹線円弧踏面，レールは $60 \mathrm{~kg}$ レールの設計プロフィールとした.ここでは回送線内に存在する急曲線 $\mathrm{R} 300 \mathrm{~m} ・$ カト $180 \mathrm{~mm}$ を $60 \mathrm{~km} / \mathrm{h}$ で走行 する場合(Case1)と, 本線において曲線半径延長の割合が最も大きい $\mathrm{R} 2500 \mathrm{~m}$ ・カント $200 \mathrm{~mm}$ を $270 \mathrm{~km} / \mathrm{h}$ で走行 する場合(Case2)の 2 条件を選定し解析を実施した. 図 11 に各条件における円曲線通過中の横圧を示す. ここで 図 11 の縦軸は R300 m の円曲線走行時における進行方向第 1 軸の横圧を 1 として無次元化した值である. Case1 の場合，横圧の大きさは 1 軸 $>3$ 軸 $>4$ 軸 $>2$ 軸の順となり，台車内における進行方向前軸で大きくなる. これは 急曲線通過時に前軸のアタック角が大きくなり, 台車が操舵不足状態となるためである. 一方, Case 2 の場合, 横圧の大きさは 2 軸 $\fallingdotseq 4$ 軸 $>1$ 軸 $\fallingdotseq 3$ 軸となり台車内における進行方向後軸の方が大きくなる. これは台車が操舵 過多状態となるためである，実運用においては，進行方向が上り下りで入れ替わることを考慮すると，1曲線あ たりに作用する横圧は図 11 の右に示す結果となる。この傾向は, 図 5(b)で示した軸毎のフランジ摩耗量の関係と 定性的に一致する. また, 図 12 には, 各条件における曲線通過時の輪軸の左右変位量の最大值とそのときの接触 点の位置を示す. Case1 の R300m 通過時は最大で輪軸は $5.4 \mathrm{~mm}$ 変位し，このとき接触点は車輪フランジ部に位置 することに対して, Case2 の R2500m 通過時では輪軸は $4.5 \mathrm{~mm}$ 変位するが，このときはフランジ部までには達し ない. したがって，横圧の発生傾向及び接触点の観点から，フランジ摩耗量が 1 軸 $\fallingdotseq 4$ 軸 $>2$ 軸 $\fallingdotseq 3$ 軸となること は，分岐器などを含む急曲線通過時の台車姿勢が支配的であることが示唆される．これは，図 2 に示すように高 速鉄道では急曲線の割合は非常に小さいものの, フランジ摩耗は急曲線を低速で通過する際に多く発生する結果 
であることを示す．なお，図 8(b)よりフランジ摩耗量のピークの位置は $\mathrm{Y}=31 \mathrm{~mm}$ 付近であるが，この位置はレー ルのゲージコーナーと接触する箇所である.

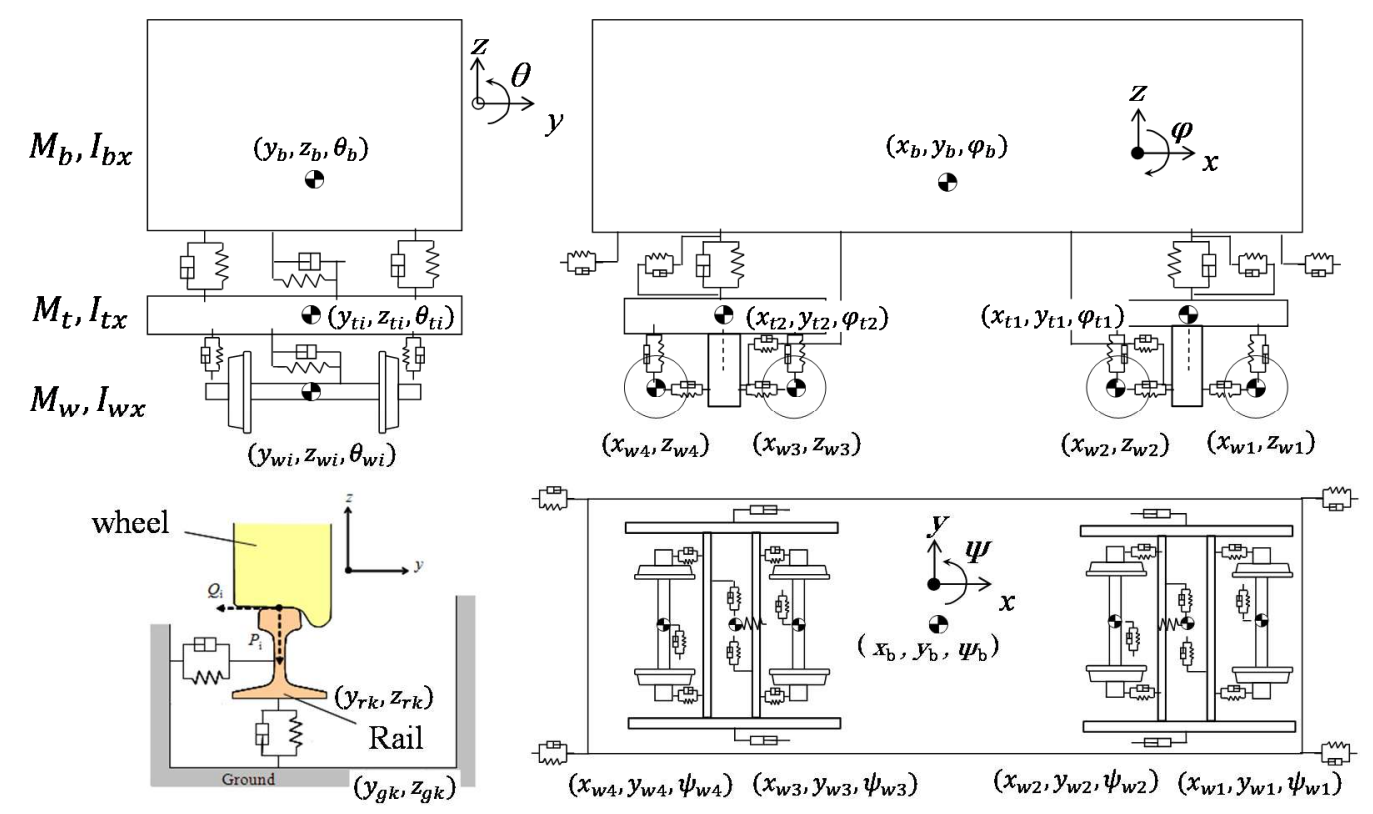

Fig.10 Vehicle/Track dynamics simulation model (Vehicle: 38 DOF, Track: 16 DOF).
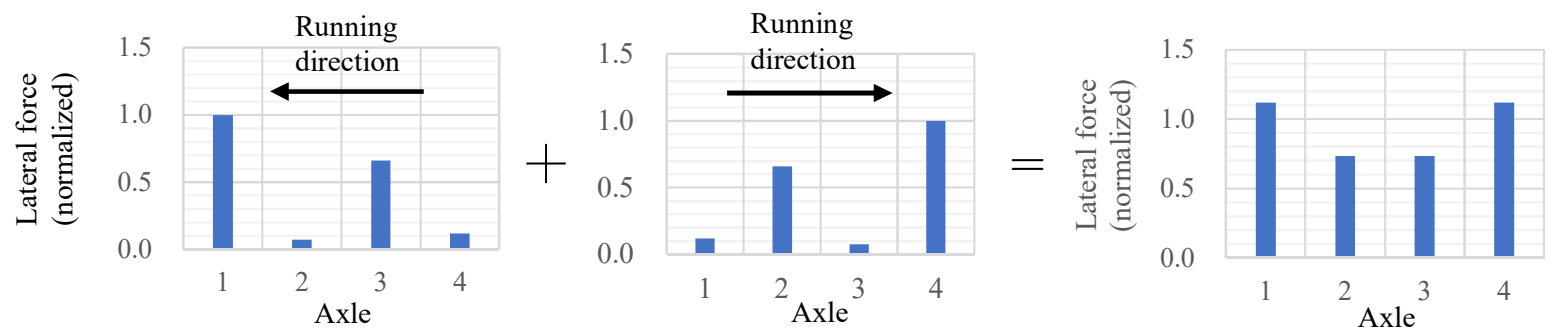

(a) Case1: Lateral force during vehicle running at sharpe curve $(\mathrm{R} 300 \mathrm{~m} \mathrm{C} 180 \mathrm{~mm})$ at $60 \mathrm{~km} / \mathrm{h}$
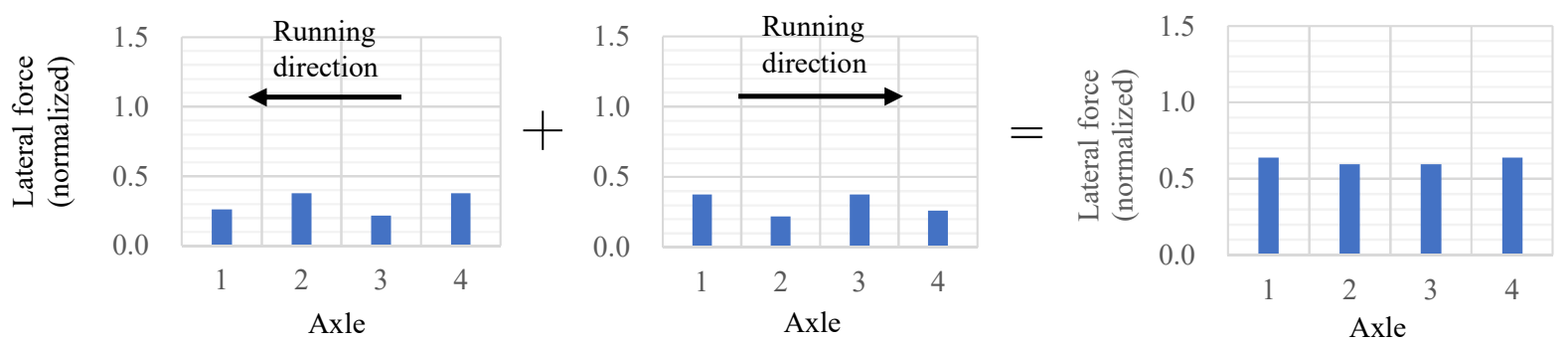

(b) Case2: Lateral force during vehicle running at gentle curve(R2500m C200mm) at $270 \mathrm{~km} / \mathrm{h}$

Fig.11 Simulation result of lateral force between wheel and rail. Case1 is passing shape curve at low speed (R300m) and Case2 is passing at gentle curve $(\mathrm{R} 2500 \mathrm{~m})$ at high speed. Right figures shows the lateral force per curve round trip for each curve.The vertical axis is nomrmalized with the lateral force of the leading axle during running at R300m. The lateral force of No.1,4 axle is larger than that of No.2,3 axle when passing R300m curve.This tendency matches field measurements of flange wear. 

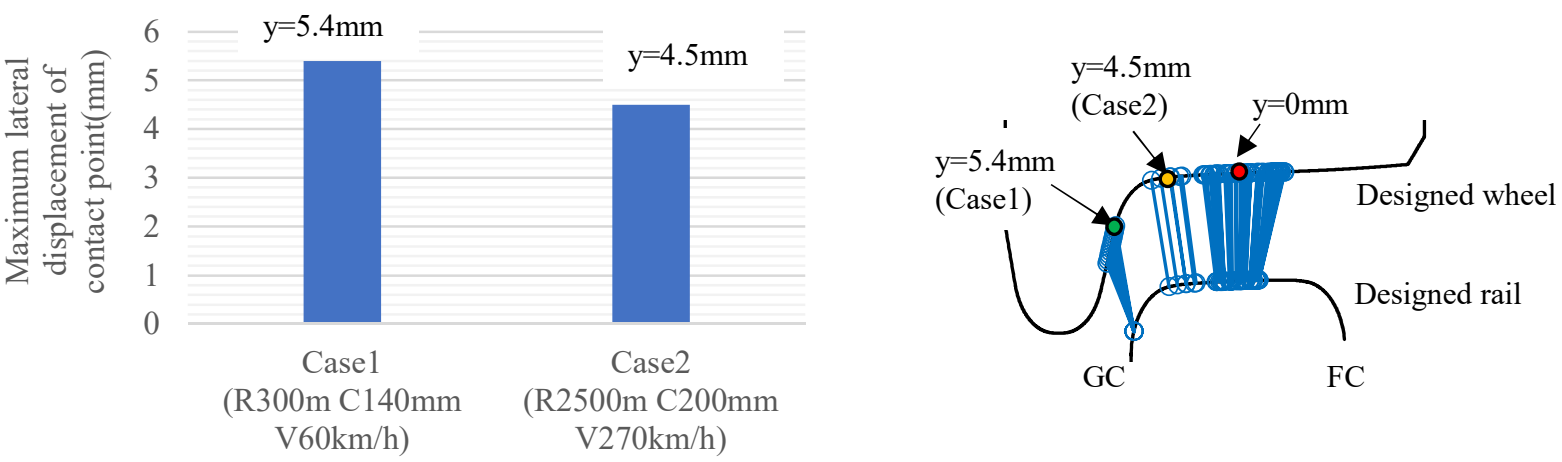

Fig.12 Simulation result of maximum lateral displaceemt of wheelset and contact positon. Wheel flange touches rail GC when passing at R300 curve(lateral displaceemt of wheelset is $\mathrm{y}=5.4 \mathrm{~mm}$ ).

\section{$3 \cdot 3$ フランジ角度}

フランジ摩耗は前節で記したように号車端部の軸 (1,4 軸) と中間軸 (2,3 軸) で傾向が異なることを示したが, フランジ角度は号車によらず比較的一定となる結果を示した（図 5(c)）。これは図 13 に示すように，定義したフ ランジ角度算出範囲（Z=12～18mm）では，フランジ摩耗が Z 位置に応じて軸によらず同じ摩耗の割合であるた めフランジの傾きが同一となるためである.

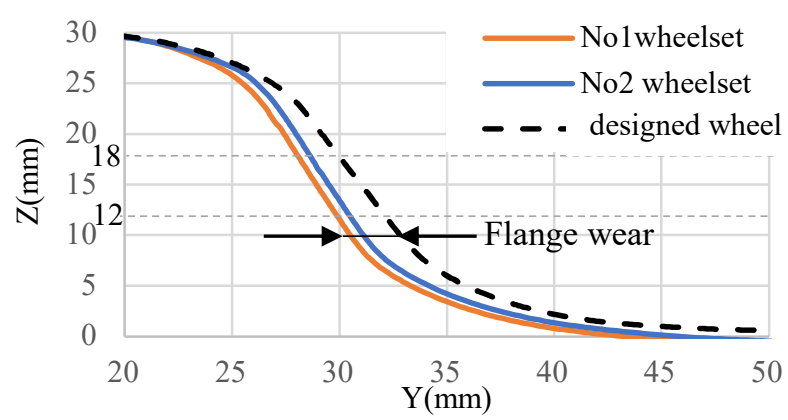

Fig.13 Relationship between flange wear and flange angle.Although the amount of flange wear varies depending on the axle number,the flange angle is the same.

\section{$3 \cdot 4$ 等価踏面勾配}

図 5(d)よりレール形状によって等価踏面勾配は異なる傾向を示す. 60kg レール設計形状との組合せにおいては, 等価踏面勾配の值はフランジ摩耗の結果と相関があり, 号車内の 2,3 軸が 1,4 軸よりもその值が大きい傾向にあ る．また，編成端部軸の 1 号車 1 軸と 16 号車 4 軸が中間車の值よりも小さくなることが分かる. このデータ傾 向については他文献でも同様の結果が報告されている（Shi et al., 2018）。これらのメカニズムについて図 14,15を 用いて説明する。図 14 に編成端部軸である 1 号車 1 軸と中間号車の代表值として 8 号車 1 軸の車輪摩耗形状を 設計車輪形状と重ねて示す。図 15 には，60kg 設計レール形状に対して 1 号車 1 軸及び 8 号車 1 軸が土 $8 \mathrm{~mm} の$ 範 囲で $0.1 \mathrm{~mm}$ 毎に左右移動したときの車輪／レールの接触点の推移とこれら輪軸の左右移動量に対する転がり半 径差 $\Delta r$ 変化を示す. 踏面部の傾きは, 摩耗進展することで設計形状に対して緩やかになるが, その傾きは 1 号 車 1 軸と 8 号車 1 軸で同程度である (図 14 右下図).このとき踏面摩耗部分ではレールと接触しにくくなるため, 車輪の中立位置での接触点は設計車輪に対してレール外側に移動する (図 15 の赤点). 一方，フランジ摩耗は先 頭号車の方が中間号車よりも進展しているため (図 14 左下図)，レールゲージコーナー（以下,レール GC) 付近 が車輪と接触するまでの輪軸の横移動距離は中間号車の方が小さくなる.すなわち，1 号車では $2.5 \mathrm{~mm}$ 横移動時 にレール GC と接触し，8 号車では $1.2 \mathrm{~mm}$ 横移動時にレール GC と接触する (困 15)。この結果，中間号車であ る 8 号車の方が先頭号車と比較し, 少ない輪軸横移動量で転がり半径差が発生するため, 等価踏面勾配は中間車 よりも両端号車の方が小さくなる. 寸なわち, フランジのど部付近の摩耗量の違いが等価踏面勾配の差に影響を 与えたものと考える. 


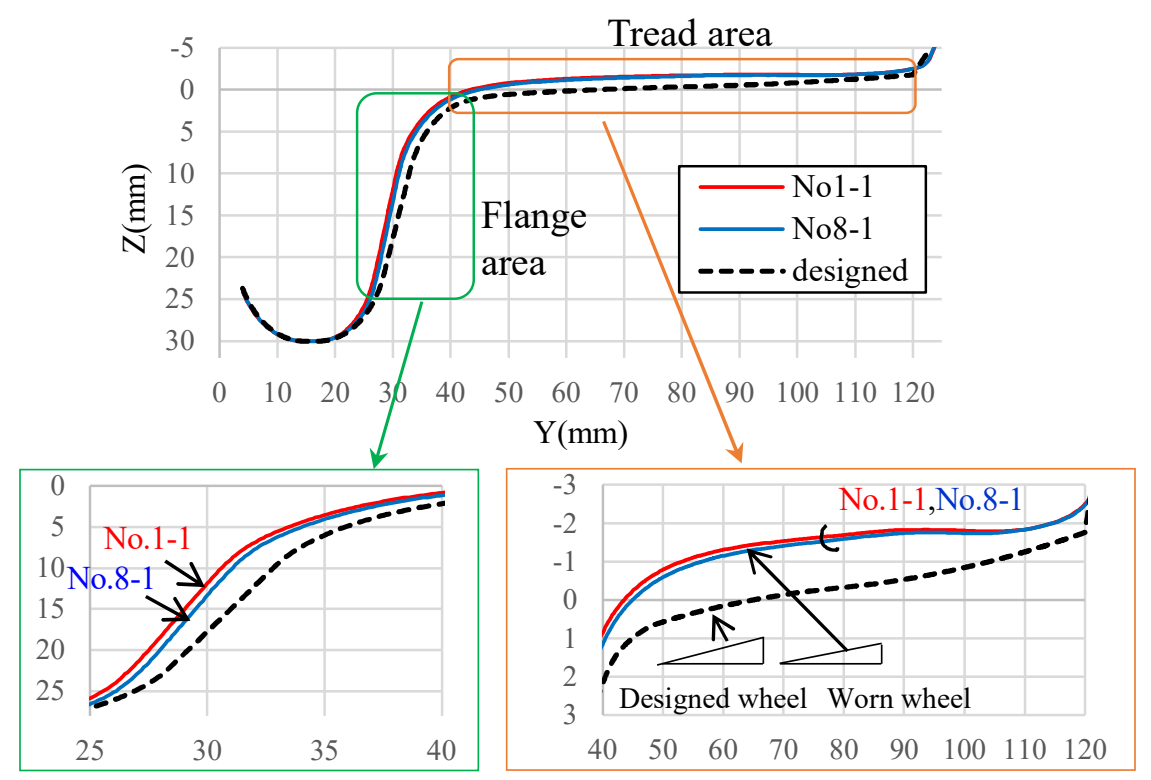

Fig.14 Comparison between designed wheel profile and wear wheel profile (No.1-1, No.8-1). The gradient of the wear tread gently becomes smaller with respect to the design shape. The flange wear of No.1-1 is larger than that of No.8-1.
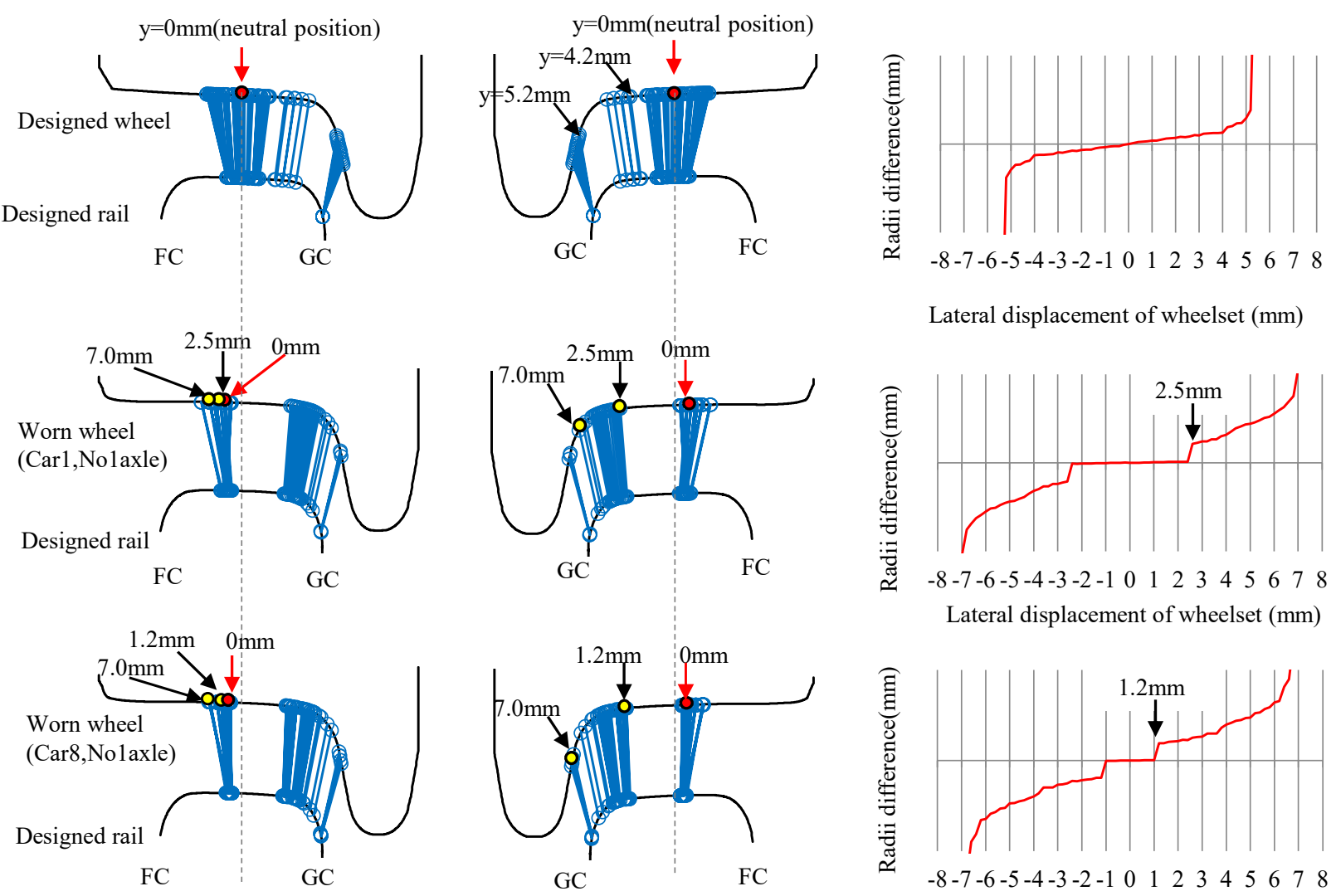

Fig.15 Wheel-rail contact point geometry relationship in the combination with 60kg designed rail shape (Top: Designed wheel, Middle: Car 1 No.1 axle, Bottom: Car 8 No.1 axle). The neutral position of the worn wheel moves to the rail FC side with respect to the design wheel and which leads to the radius difference zero at the neutral point. The lateral displacement of Car 1 until the wheel contacts the rail gage corner is smaller than that of Car 8(Car 1 contacts the rail GC when moving $2.5 \mathrm{~mm}$ laterally, Car 8 contacts when moving $1.2 \mathrm{~mm}$ ), because the flange wear of Car 1 is larger than that of Car 8 . As a result, the equivalent conicity of Carlis smaller than for that of Car 8. 
一方，図 5(d)より削正後レール形状（実測形状）との組合せにおいては，60kg 設計レール形状との組合せ結果 よりも低い值を取り，また号車に依らずその值は一定值をとる. 図 16 に削正後レール形状における接触点の推移 とこれら輪軸の左右移動量に対する転がり半径差 $\Delta r$ の変化を示す. 図 16 より削正後レール形状との組合せ結果 では，車輪の摩耗形状に依らず接触点の推移は同程度となることが分かる。これは，図 6 で示したように削正後 レール形状ではレール GC 付近が削正されるため，レール GC 付近が車輪と接触するまでの輪軸の横移動距離は いずれも $5.0 \mathrm{~mm}$ 以上と $60 \mathrm{~kg}$ 設計レール形状と比較し大きくなり，本報で定義した等価踏面勾配（ $y= \pm 3 \mathrm{~mm}$ 内 における線形近似から求まる傾き）ではその差が現れないためである.
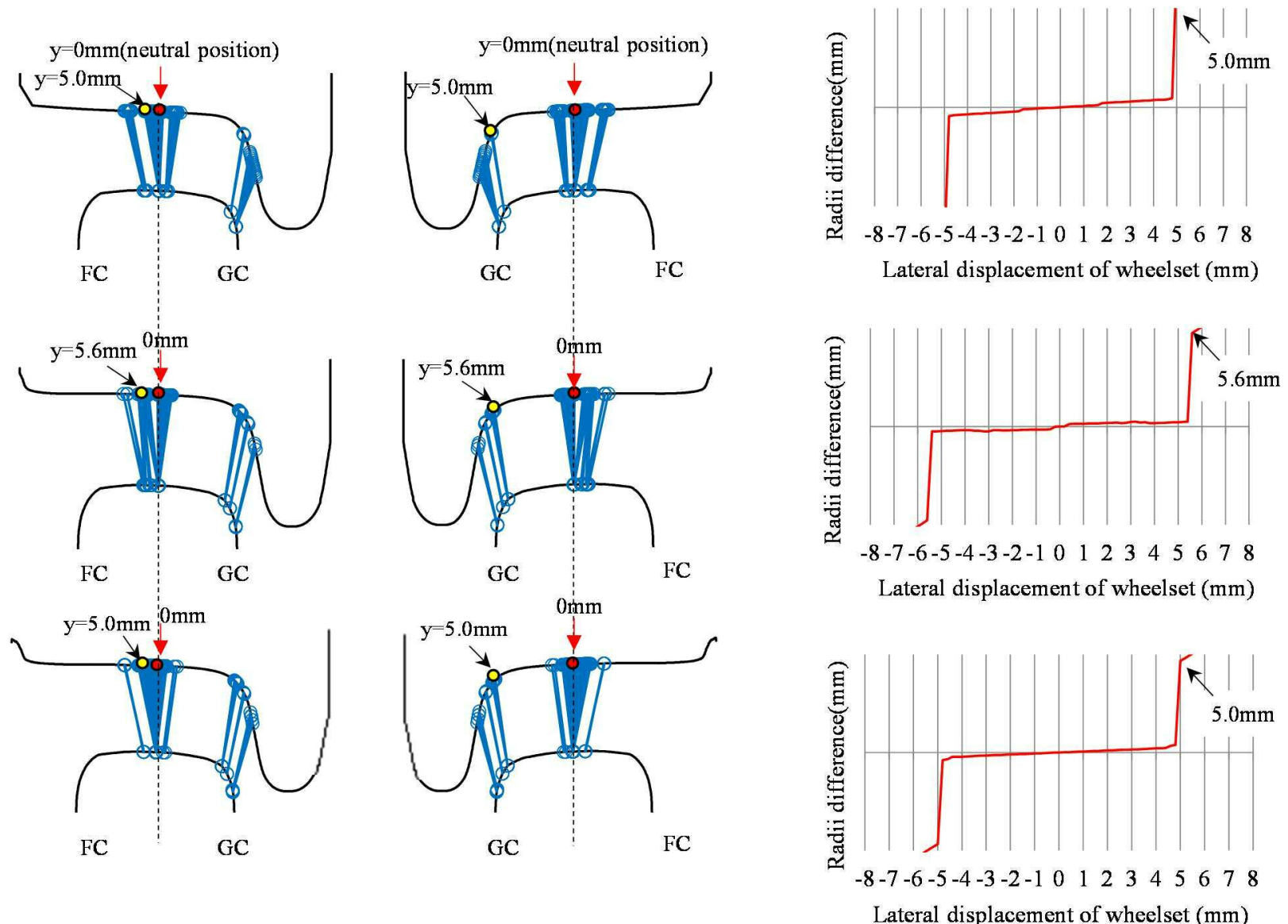

Fig.16 Wheel-rail contact point geometry relationship in the combination with ground rail shape (Top: Designed wheel, Middle: Car 1 No.1 axle, Bottom: Car 8 No.1 axle). It's the same regardless of worn wheel shape.

\section{4. 結 言}

本研究では，車輪摩耗の進み度合いを表す摩耗係数についてフィールドデータから同定する可能性を検討する ために，東海道新幹線区間を走行する新幹線車両を対象として大量の車輪形状データを取得・分析し，その結果 明らかとなった車輪摩耗特性について考察を加えた. 本研究で得られた知見を以下に示寸.

・フィールドデータに基づき, N700A タイプ車両における号車・軸毎の車輪摩耗特性を明らかにした.

・ N700A タイプ車両における号車・軸毎の摩耗傾向は同程度であり, 走行条件・車両性能が統一された状態に ある鉄道システムにおいては，大量のフィールドデータを収集・分析することで，平均的な摩耗形状を一般 化できることが示唆され，摩耗による車輪形状変化を予測する上で必要となる摩耗係数についてフィールド データから同定できる可能性を得た。

・ 踏面摩耗・フランジ摩耗については, 編成内における端部号車の方が中間号車よりも摩耗量が大きくなる. このうちフランジ摩耗については，号車によらず軸別の傾向が明らかであり，号車端部軸の方が中間軸より も大きくなる．これは，急曲線走行時の台車姿勢に起因することを数值シミュレーションにより示した. 
・等価踏面勾配についてはレール形状との組合せによって結果が異なることが確認され，60kg 設計レールと摩 耗車輪との組合せにおいては，フランジのど部付近の摩耗量の違いによりその特徵が決定されることを示し た.

\section{文献}

足立雅和，下村隆行，佐藤栄作，車輪とレールの摩耗を考慮した接触状態解析手法の開発，鉄道総研報告，Vol.20， No.6(2006),pp.17-22.

Braghin, F., Lewis, R., Dwyer-Joyce, R.S. and Bruni, S., A mathematical model to predict railway wheel profile evolution due to wear, Wear, Vol.261(2006), pp.1253-1264.

Casanueva, C., Enblom, R., Stichel, S. and Berg, M., On integrated wheel and track damage prediction using vehicle-track simulations, Proc.ImechE, partF: Journal of Rail and Rapid Transit, Vol.231, Issue7(2017), pp.775-785.

藤本裕，宮本昌幸，島本洋一，新幹線電車の左右振動とその対策，鉄道総研報告, Vol.9, No.1(1995).

Jendel, T., Prediction of wheel profile wear comparisons with field measurements, Wear, Vol.253(2002), pp.89-99.

金鷹，名村明，石田誠，レール頭部の摩耗形状予測手法，鉄道総研報告，Vol.23，No.2 (2009), pp.5-10.

角井真哉, 五十川敬司, 真野辰哉, 修正円弧踏面とレールの相互作用による車輪半径差特性調査, J-Rail2004(2004), pp.359-362.

Lewis, R. and Dweyer-Joyce, R.S., Wear mechanisms and transitions in railway wheel steel, Proc.ImechE, partJ:Engineering Tribology, Vol.218, Issue6(2004), pp.467-478.

Luo, R., Shi, H., Teng, W. and Song, C., Prediction of wheel wear and vehicle dynamics evolution considering stochastic parameters for high-speed train, Wear, Vol.392-393(2017), pp.126-138.

三輪昌弘，飯田研吾，勝浦克仁，友善守，車輪接触と車両運動を考慮した新幹線のレール削正，J-Rail2012(2012), pp.653-656.

中橋順一，三宮大輝，川上正一郎，谷本啓，車輪摩耗形状の生成メカニズムの基礎検討，鉄道総研報告，Vol. 30, No.11(2006), pp.5-10.

西村和彦，瞱道佳明，森村勉，曾我部潔，振動軌道上における高速鉄道車両の走行安全性に関する解析的研究，

日本機械学会論文集 C 編, Vol.74, No.744(2008), pp.93-100.

Pearce, T.G. and Sherratt, N.D., Prediction of wheel profile wear, Wear, Vol.144(1991), pp.343-351.

Pombo, J., Ambrosio, J., Pereira, M., Lewis, R. and Dwyer-Joyce, R.S., A mathematical wheel wear prediction tool based on a multibody software, Journal of Theoretical and Applied mechanics, Vol.48, No.3(2010), pp.751-770.

斎藤憲司，佐藤栄作，下村孝行，芳賀昭弘，大戸伸一，新型通勤車輪の車輪摩耗傾向及び車両運動特性，鉄道総 研報告, Vol.21, No.7(2007), pp.45-50.

坂本裕一郎，山下道寛，駆動力変動による編成電車の車体前後振動解析，鉄道総研報，Vol.32, No.8(2018), pp.1722.

Shi, H., Wang, J., Wu, P., Song, C. and Ten,W., Field measurements of the evolution of wheel wear and vehicle dynamics for high speed trains, Vehicle System Dynamics, Vol.56, Issue8(2018), pp.1187-1206.

清水惇, 飯田忠文, 小木曾清高, $60 \mathrm{~kg} レ$ レ頭頂面の形状変更が車両走行特性に及ぼす影響評価, 鉄道総研報告, Vol.28, No.6(2014), pp.29-34.

下川嘉之, 亀甲智, 斎藤拓也, 岩本厚, 荻野智久, 鈴木芳明, 谷藤克也, 車輪の摩耗予測に関する研究（第 1 報, 試験片を用いた摩耗試験結果，J-Rail2010(2010),pp.645-648.

滝野雄一郎，林世涁，須田義大，影山真佐富，谷本篤嗣，古賀進一郎，湿潤状態における車輪列の摩擦特性， J-Rail2013(2013), pp.87-90.

Tao, G., Du, X., Zhang, H., Wen, Z., Jin, X. and Cui, D., Development and validation of a model for predicting wheel wear in high-speed trains, Journal of Zhejiang University-SCIENCE A, Vol.18, No.8 (2017), pp.603-618.

谷藤克也，車輪摩耗形状の予測を目指して，JREA, Vol.55, No.5(2012), pp.4-6.

谷藤克也, 咲山武司, 新幹線電車の車輪摩耗特性と走行振動 $1 / 40$ こう配の円すい踏面車輪の場合, 日本機械学 会論文集 C 編, Vol.53, No.492(1986), pp.1743-1749.

辻江正裕, 吉岡亜陸, 水谷祐貴, 瞱道佳明, マルチボディダイナミクスによるレール摩耗形状予測モデルの構築 と妥当性の検証, 日本機械学会論文集, Vol.83, No.854(2017), DOI:10.1299/transjsme.17-00074.

上野雅之，菊野敏，東海道新幹線の最新ブレーキ粘着技術，JREA，Vol.54, No.5(2011), pp.27-32. 


\section{References}

Adachi, M., Shimomura, T. and Sato, E., Developmenet of evaluation system of geometrical characteristics of contact point between wheel and rail with consideration of wear, RTRI Report, Vol. 20, No.6(2006), pp.17-22 (in Japanese).

Braghin, F., Lewis, R., Dwyer-Joyce, R.S. and Bruni, S., A mathematical model to predict railway wheel profile evolution due to wear, Wear, Vol.261(2006), pp.1253-1264.

Casanueva, C., Enblom, R., Stichel, S. and Berg, M., On integrated wheel and track damage prediction using vehicle-track simulations, Proc.ImechE, partF:Journal of Rail and Rapid Transit, Vol.231,Issue7(2017), pp.775-785.

Fujimoto, H., Miyamoto, M. and Shimamoto, Y., Lateral vibration and its decreasing measure in the tail car of a skinkansen, RTRI Report, Vol.9, No.1(1995) (in Japanese).

Jendel, T., Prediction of wheel profile wear comparisons with field measurements, Wear, Vol.253(2002), pp.89-99.

Jin, Y., Namura, A. and Ishida, M., A predictive method of wear profile of rail head, RTRI Report, Vol.23, No.2 (2009), pp.510 (in Japanese).

Kakui, S., Isogawa, K. and Mano, T., Investigation in characteristics of the difference in radius between two wheels in one axle by mutural wear of "modified arc wheel profile" and a rail, J-Rail2004(2004), pp.359-362(in Japanese).

Lewis, R. and Dweyer-Joyce, R.S., Wear mechanisms and transitions in railway wheel steel, Proc.ImechE, partJ:Engineering Tribology, Vol.218, Issue6(2004), pp.467-478.

Luo, R., Shi, H., Teng, W. and Song, C., Prediction of wheel wear and vehicle dynamics evolution considering stochastic parameters for high-speed train, Wear, Vol.392-399 (2017), pp.126-138.

Miwa, M., Iida, K., Katsuura, K. and Tomoyoshi, M., Rail grinding for Shinkansen in consideration if wheel contact and vehicle dynamics, J-Rail2012(2012), pp.656-659(in Japanese).

Nakahashi, J., Sannomiya, D., Kawakami, S. and Tanimito, K., Fundamental study of the generation mechanism of the wheels wear shapes, RTRI Report, Vol. 30, No.11(2006), pp.5-10 (in Japanese).

Nishimura, K., Terumichi, Y., Morimura, T. and Sogabe, K., Analtical study on the safety of high speed railway vehicle on excited tracks, Transactions of the Japan Society of Mechanical Engineers,Series C, Vol.74, No.744 (2008), pp.93-100 (in Japanese).

Pearce, T.G. and Sherratt, N.D., Prediction of wheel profile wear, Wear, Vol.144(1991), pp.343-351.

Pombo, J., Ambrosio, J., Pereira, M., Lewis, R. and Dwyer-Joyce, R.S., A mathematical wheel wear prediction tool based on a multibody software, Journal of Theoretical and Applied mechanics, Vol.48, No.3 (2010), pp.751-770.

Saito, K., Sato, E., Shimomura, T., Haga, A. and Ooto, S., Wheel wear and vehicle dynamics characteristics of the new type commuter train, RTRI Report, Vol.21, No.7(2007), pp.45-50 (in Japanese).

Sakamoto, Y. and Yamashita, M., Longitudinal vibration analysis in the train set caused by tractive force variation, RTRI Report, Vol. 32, No.8(2018), pp.17-22(in Japanese).

Shi, H., Wang, J., Wu, P., Song, C. and Ten,W., Field measurements of the evolution of wheel wear and vehicle dynamics for high speed trains, Vehicle System Dynamics, Vol.56, Issue8(2018), pp.1187-1206.

Shimizu, A., Iida, T. and Ogiso, K., Analyzing the effect of the profile change of top surface of $60 \mathrm{~kg}$ rail upon the vehicle dynamics, RTRI Report, Vol.28, No.6(2014), pp.29-34(in Japanese).

Shimokawa, Y., Kikko, S., Saito, T., Iwamoto, A., Ogino, T., Suzuki, Y. and Tanifuji, K., A study on wear prediction of railway wheel(1st report, Bench test), J-Rail2010(2010), pp.645-648 (in Japanese).

Takino, Y., Lin, S., Suda, Y., Kageyama, M., Tanimoto, A. and Koga, S., Study on friction characteristics of the multiple wheels in wet condition, J-Rail2013(2013), pp.87-90(in Japanese).

Tao, G., Du, X., Zhang, H., Wen, Z., Jin, X. and Cui, D., Development and validation of a model for predicting wheel wear in high-speed trains, Journal of Zhejiang University-SCIENCE A, Vol.18, No.8(2017), pp.603-618.

Tanifuji, K., Challenge to predict wheel wear profile, JREA,Vol.55, No.5(2012), pp.4-6 (in Japanese).

Tanifuji, K. and Sakiyama, T., The characteristics of wheel wear in Shinkansen electric cars and its effect to the running vibration, Transactions of the Japan Society of Mechanical Engineers, Series C, Vol.53, No.492(1986), pp.1743-1749(in Japanese).

Tsujie, M., Yoshioka, A., Mizutani, Y. and Terumichi, Y., A study on the modelling for prediction worn profile of rail with multi-body dynamics and the verifying the validity, Transactions of the JSME (in Japanese), Vol.83, No.854(2017), DOI:10.1299/transjsme.17-00074.

Ueno, M. and Kikuno, S., The latest brake technologies of Tokaiso-Shinkansen, JREA, Vol.54, No.5(2011), pp.27-32(in Japanese). 